\title{
Personal and professional development of additional education teacher in the course of methodological work
}

\author{
Zhanna Chaykina ${ }^{1 *}$, Mariia Mukhina ${ }^{1}$, Marina Gruzdeva $^{1}$, Olga Cherney $^{1}$, and Olga \\ Golubeva $^{1}$ \\ ${ }^{1}$ Minin Nizhny Novgorod State Pedagogical University, Department of Technology of Service and \\ Technological Education, Nizhny Novgorod, Russia
}

\begin{abstract}
The contemporary development strategy of Russian education puts forward several requirements for the system of additional education for children and teachers engaged in this field. The teacher must have the ability to self-development and self-improvement, be engaged in creative and innovative activities. The authors note that in the current conditions, the teacher must choose the only correct trajectory of professional advancement that will lead to the achievement of the desired results. The individual trajectory of personal and professional development of a teacher can be represented as a trajectory of professional self-development and self-improvement of a teacher of additional education in the course of teacher's methodological work. The purpose of the current research is to develop, theoretically substantiate, and experimentally test the program for implementing an individual trajectory of personal and professional development of additional education teacher in the course of teacher's methodological work. Implementation of individual trajectories of personal and professional development of additional education teachers in the educational organization involves the development of a specific action plan of the heads of departments, educational and methodological service of the institution, as well as very additional education teachers. The tasks of the educational and methodical service of an educational organization in this process are aimed at encouraging teachers, attracting them to innovative activities, various types of methodological work, and providing pedagogical and methodological support. The use of individual trajectory of personal and professional development in the course of organizing methodological work in the educational organization of additional education contributes to an increase in the professional competence of teachers as well as the development of their interest in this process.
\end{abstract}

Keywords: teacher, additional education, individual trajectory, personal and professional development.

* Corresponding author: jannachaykina@mail.ru 


\section{Introduction}

The contemporary system of additional education of children in Russia was created based on unique Russian forms of extracurricular work and the best experience of predecessor teachers, educators, as well as the rich heritage of not only Russian but also international pedagogy.

Recently, there has been dynamic development of additional education: the range of services provided is expanding, the forms and methods of work are being improved, and modern information technologies are being implemented. The implementation of these activities imposes several requirements on the personality and competence of additional education teacher. In the flow of rapidly changing innovations, the teacher must choose the only correct trajectory of professional advancement that will lead to the achievement of the desired results, i.e. an individual trajectory of personal and professional development.

The individual trajectory of personal and professional development is considered in this study as a trajectory of professional self-development and self-improvement of a teacher of additional education in the course of teacher's methodological work. Professional selfdevelopment and self-improvement of teachers are primarily due to their interest in improving their own professional skills and competencies. The tasks of the educational and methodological service of an educational organization in this process are to stimulate teachers, attract them to innovative activities, various types of methodological work, and provide them with pedagogical and methodological support.

Analysis of domestic research in the field of additional education [1-8] as well as the requirements of the professional standard to additional education teacher allows highlighting the distinctive features of the today's additional education teacher who

- is continuously acquiring new professional and psycho-pedagogical knowledge;

- is developing creativity and ability to innovate;

- is designing new educational technologies;

- is striving for self-development and self-improvement.

The above stated actualizes the need for the constant personal and professional development of additional education teacher.

But at the same time, the existing programs of teachers' professional development are mainly implemented in the framework of activities that prepare teachers for certification for a certain qualification category. Most often, such programs do not take into account the current level of personal and professional development of teachers, their educational needs and development prospects, requirements and features of educational activities of a specific organization of additional education for children, and are implemented remotely from the teachers' principal places of employment. In this regard, the present study has identified the problem of revealing opportunities for the personal and professional development of additional education teachers, taking into account contemporary requirements of the professional standard, individual needs of each teaching employee, and resources of an educational organization.

Thus, the following hypothesis has been put forward: the personal and professional development of additional education teachers will be successful if their methodological work will be organized based on an individual trajectory of personal and professional development.

The purpose of the present research was to develop, theoretically substantiate, and experimentally test the program for implementing an individual trajectory of personal and professional development of additional education teachers in the course of their methodological work.

The research included the following objectives:

a) analyzing scientific psychological, pedagogical, and methodological literature; 
b)developing program, performance assessing criteria, and selecting diagnostic methods;

c)conducting experimental work and analyzing its results.

\section{Methods}

In the course of the study, based on the analysis of the works of scientists who reveal different approaches to the process of pedagogical competence formation [9-15], three main stages were identified in the course of professional formation of additional education teacher, namely, initial, basic, and high. Each stage is characterized by a certain level of teacher's personal development and professional training, which determines the effectiveness and quality of the educational process. Thus, at the first stage, teacher acquires and develops pedagogical competencies (knowledge and skills); at the second stage, teacher develops creative abilities to innovate (experience), and at the third stage, teacher masters new pedagogical techniques and technologies (forming pedagogical skills).

To design an individual trajectory of personal and professional development of additional education teacher, first, it was necessary to conduct diagnostics of the current level of teacher's personal and professional development.

During the experimental work, the level of personal and professional development of additional education teacher was determined based on the total value of four criteria reflecting the personal and professional development of a teacher. These were as follows:

- motivational criterion determining teacher's interest in personal and professional development;

- cognitive criterion characterizing the readiness and ability of a teacher to acquire professional knowledge in the field of psychological and pedagogical sciences;

- activity criterion revealing the ability of a teacher to develop additional educational programs and classes with students based on innovative pedagogical technologies;

- personal criterion indicating teacher's ability to assess and regulate their own personal and professional development.

Taking into account the selected criteria and based on the assessment diagram of professionally significant personal qualities (developed by G.S. Kovaleva), a questionnaire was developed for additional education teachers. This questionnaire was used at the ascertaining and control stages of the experimental work.

More than 30 teachers of additional education with different work experience from 0 to 30 years from various structural divisions of the Center for Children's Creativity of the Avtozavodsky District of Nizhny Novgorod were involved in the experimental work. After determining the current level of personal and professional development, teachers, according to their desire, were assigned to two groups, namely, control and experimental. Both groups included the same number of participants and approximately the same distribution of teachers by personal and professional development level. The control group of teachers was engaged in methodological and educational activities according to the standard work plan of the educational organization. The experimental group of teachers worked on a specially designed program for the development of personal and professionally important qualities.

Within the framework of the program, three directions were identified for the implementation of an individual trajectory of personal and professional development of additional education teachers, depending on the identified level of development of personal and professionally important qualities. Each direction of the individual trajectory of personal and professional development of teachers had a key task and assumed certain content of the teachers' methodological work.

The main content of the methodological work depending on the level of personal and professional development of teachers was as follows: 
a) initial level -self-tutoring, participating in seminars, masterclasses, webinars, and training in advanced training courses;

b) base level - participating in methodological contests, developing methodological recommendations, teaching materials, participating in procedure development to exchange experiences;

c) high level - developing authorial programs, participating in teaching skills competitions, organizing and conducting seminars and workshops.

The revealed actual level of personal and professional development of teachers allowed determining their individual vector of personal and professional development trajectory and correcting their methodological work content.

\section{Results}

The results of the conducted experimental work (Fig. 1) have shown that in the control group, the number of teachers with a low level of personal and professional development did not change before and after the experiment, and amounted to $10 \%$. The number of teachers with middle and high level of development remained virtually unchanged before and after the experiment.

The experimental group of teachers participating in the personal and professional development program and carrying out methodological work on an individual trajectory has shown an increase in the number of teachers with a high level of personal and professionally important qualities by $15 \%$ and a decrease by $10 \%$ in the number of teachers with a low level of personal and professionally important qualities.

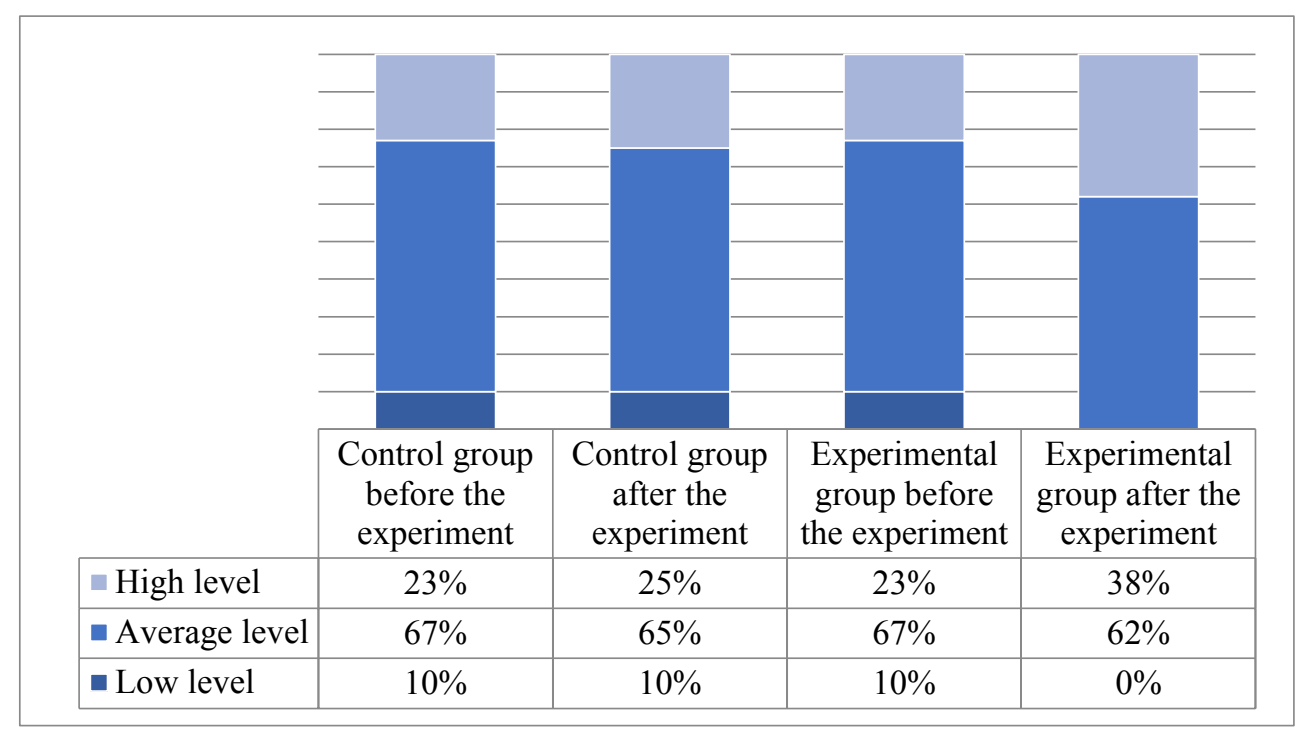

Fig. 1. Diagram of the development levels of personal and professionally important qualities of teachers in the control and experimental groups.

Thus, the experimental study has confirmed the made assumption that the personal and professional development of teachers will be effective if they use an individual trajectory of personal and professional development in the course of their methodological work. 


\section{Discussion}

Implementation of individual trajectories of personal and professional development of additional education teachers in the educational organization involves the development of a specific action plan of the heads of departments, educational and methodological service of the institution, and very additional education teachers. Professional self-development and self-improvement of teachers occur primarily due to their interest in improving their own professional skills and competencies. The tasks of the educational and methodical service of an educational organization in this process are to encourage teachers, attract them to innovative activities, various types of methodological work, and provide pedagogical and methodological support.

The use of individual trajectories of personal and professional development in the course of organizing methodological work in an educational organization of additional education contributes to the improvement of the professional competence of teachers, promoting their interest in this process.

The material developed in the course of the research can be used when creating certification and other measuring materials to assess the quality of activities of teachers and educational organizations of additional education for children.

\section{Conclusion}

Personal and professional development of additional education teacher in the course of methodological work in an additional education institution involves the implementation of a set of measures for organizational and methodological support of the teacher's innovative and other methodological activities. The content and nature of organizational and methodological support are determined by the framework of the individual trajectory of professional development of a teacher of an educational organization involved in children's additional education.

\section{References}

1. V.A. Berezina, Dopolnitel'noye obrazovaniye detey v Rossii [Additional education for children in Russia] (Dialog kultur, Moscow, 2007)

2. L.N. Buylova, Young scientist, 15, 567-572 (2015)

3. L.N. Buylova, Mir nauki, kultury, obrazovaniya, 6(31), 130-134 (2011)

4. A.V. Zolotareva, Dopolnitel'noye obrazovaniye detey: istoriya i sovremennost' [Additional education of children: history and modernity] (Yurayt, Moscow, 2018)

5. Ye.B. Yevladova, Vneurochnaya deyatel'nost' kak prostranstvo razvitiya samoorganizatsii shkol'nikov [Extracurricular activities as a space for the development of self-organization of schoolchildren], in "Tsifrovoye pokoleniye" i pedagogicheskiye realii sovremennoy Rossii: nauchno-prakticheskaya internetkonferentsii s mezhdunarodnym uchastiyem (Institute of Study of Childhood, Family and Education of the Russian Academy of Education, Moscow, 2017)

6. L.G. Loginova, Moscow, Teoriya i praktika dopolnitelnogo obrazovaniya, 2, 12 (2015)

7. L.G. Loginova, Vospitaniye shkolnikov, 5, 49-56 (2016)

8. V.A. Karnaukhova, T.G. Semusheva, Azimuth of scientific research: pedagogy and psychology, 8(2 (27)), 112-115 (2019) 
9. V.N. Vvedensky, Professional'naya kompetentnost' pedagoga [Professional competence of the teacher] (Prosveshcheniye, Saint Petersburg, 2004)

10. V.N. Vvedensky, Gumanitarnyye nauchnyye issledovaniya, 10 (2015). Accessed on: September 16, 2020. [Online]. Available: http://human.snauka.ru/2015/10/12067

11. A.K. Markova, Psikhologiya professionalizma [Psychology of professionalism] (International Humanitarian Public Foundation Znanie, Moscow, 1996)

12. L.M. Mitina, Professional'naya evolyutsiya i kar'yernyy rost sovremennogo cheloveka: sistemnyy lichnostno-razvivayushchiy podkhod [Professional evolution and career growth of a modern person: a systemic personal developmental approach], in Lichnostno-professional'noye i kar'yernoye razvitiye: aktual'nyye issledovaniya i forsayt-proyekty, 3-6 (Pero, Moscow, 2018)

13. L.M. Mitina, Psikhologiya professional'nogo i kar'yernogo razvitiya: teoreticheskiye $i$ prikladnyye aspekty [Psychology of professional and career development: theoretical and applied aspects], in Sistemogenez uchebnoy i professional'noy deyatel'nosti. Part I, 254-257 (RIO, Yaroslavl, 2018)

14. L.M. Mitina, Psychological patterns of personal and professional evolution/involution of the subjects of education, in Proceedings of the 7th World conference on educational technology researches (WCETR-2017), AAB College, 20-22 April 2017, Pristina Republic of Kosovo (2017)

15. L.A. Ovchinnikova, I.Ye. Dekman, Azimuth of scientific research: pedagogy and psychology, 9(2(31)), 354-357 (2020) 